\title{
Temozolomide promotes genomic and phenotypic changes in glioblastoma cells
}

\author{
Aleksei A. Stepanenko ${ }^{1 *}$, Svitlana V. Andreieva ${ }^{1}$, Kateryna V. Korets ${ }^{1}$, Dmytro O. Mykytenko ${ }^{1}$, \\ Vladimir P. Baklaushev²,3, Nataliya L. Huleyuk', Oksana A. Kovalova ${ }^{5}$, Kateryna V. Kotsarenko ${ }^{6}$, \\ Vladimir P. Chekhonin², Yegor S. Vassetzky ${ }^{7}$, Stanislav S. Avdieiev ${ }^{1}$ and Vladimir V. Dmitrenko ${ }^{1 \wedge}$
}

\begin{abstract}
Background: Temozolomide (TMZ) is a first-line drug for the treatment of glioblastoma. Long-term TMZ-treated tumour cells acquire TMZ resistance by profound reprogramming of the transcriptome, proteome, kinome, metabolism, and demonstrate versatile and opposite changes in proliferation, invasion, in vivo growth, and drug crossresistance. We hypothesized that chromosomal instability (CIN) may be implicated in the generation of TMZ-driven molecular and phenotype diversity. CIN refers to the rate (cell-to-cell variability) with which whole chromosomes or portions of chromosomes are gained or lost.
\end{abstract}

Methods: The long-term TMZ-treated cell lines were established in vitro (U251TMZ1, U251TMZ2, T98GTMZ and C6TMZ) and in vivo (C6R2TMZ). A glioma model was achieved by the intracerebral stereotactic implantation of C6 cells into the striatum region of rats. Genomic and phenotypic changes were analyzed by conventional cytogenetics, array CGH, trypan blue exclusion assay, soft agar colony formation assay, scratch wound healing assay, transwell invasion assay, quantitative polymerase chain reaction, and Western blotting.

Results: Long-term TMZ treatment increased CIN-mediated genomic diversity in U251TMZ1, U251TMZ2 and T98GTMZ cells but reduced it in C6TMZ and C6R2TMZ cells. U251TMZ1 and U251TMZ2 cell lines, established in parallel with a similar treatment procedure with the only difference in the duration of treatment, underwent individual phenotypic changes. U251TMZ1 had a reduced proliferation and invasion but increased migration, whereas U251TMZ2 had an enhanced proliferation and invasion but no changes in migration. U251TMZ1 and U251TMZ2 cells demonstrated individual patterns in expression/activation of signal transduction proteins (e.g., MDM2, p53, ERK, AKT, and ASK). C6TMZ and C6R2TMZ cells had lower proliferation, colony formation efficiency and migration, whereas T98GTMZ cells had increased colony formation efficiency without any changes in proliferation, migration, and invasion. TMZ-treated lines demonstrated a differential response to a reduction in glucose concentration and an increased resistance to TMZ re-challenge but not temsirolimus (mTOR inhibitor) or U0126 (MEK1/2 inhibitor) treatment.

Conclusion: Long-term TMZ treatment selected resistant genotype-phenotype variants or generated novel versatile phenotypes by increasing CIN. An increase of resistance to TMZ re-challenge seems to be the only predictable trait intrinsic to all long-term TMZ-treated tumour cells. Changes in genomic diversity may be responsible for heterogeneous phenotypes of TMZ-treated cell lines.

Keywords: Aneuploidy, Chromosome instability, Drug resistance, Glioma, Karyotype, Heterogeneity

\footnotetext{
*Correspondence: a.a.stepanenko@gmail.com

1 Department of Biosynthesis of Nucleic Acids, Institute of Molecular

Biology and Genetics, National Academy of Science of Ukraine,

Zabolotnogo str. 150, Kiev 03680, Ukraine

Full list of author information is available at the end of the article

Deceased: Vladimir V. Dmitrenko
} 


\section{Background}

Temozolomide (TMZ), an imidazotetrazine derivative of the alkylating agent dacarbazine, is a first-line drug for the treatment of patients with glioblastoma. However, the TMZ efficiency is quite modest, with median overall survival ranging 9.4-19.0 months for radiotherapy combined with TMZ versus 7.3-17.1 months for radiotherapy alone [1]. TMZ is also used in the treatment of brain metastases, melanoma, lymphomas, refractory leukaemia, neuroendocrine tumours, pituitary tumours, Ewing's sarcoma, primitive neuroectodermal tumours, lung cancer and other tumours [2]. Most tumour cells are intrinsically resistant or rapidly acquire resistance to TMZ at pharmacotherapeutic concentrations [3-6]. Long-term TMZ treatment of glioblastoma cells induced profound changes in heterochromatin organization and DNA methylation [7], transcriptome [8-12], proteome [13, 14], kinome [15], and metabolome [8, 10], remodeling of the entire electron transport chain and activation of oxidative stress responses [16, 17]. These changes impacted morphology, proliferation, adhesion, migration, invasion, and drug cross-resistance in a versatile manner $[7,8,14,18-23]$. Such a complex phenotype adaptation certainly indicates intricate cellular and molecular defense mechanisms against TMZ. Additionally, the versatile phenotype responses to long-term TMZ treatment (Table 1) may point to the TMZ-promoted genome changes, which affect the organization and functionality of the genetic network (gene content, RNA and protein expression and their interaction). In fact, an acquisition of chemotherapy resistance is generally accompanied by genome evolution and, conversely, chromosomal instability (CIN) correlates with (multi)drug resistance [24-34].

CIN refers to the rate of gain or loss of whole chromosomes and portions of chromosomes, whereby the rate is defined as cell-to-cell variability or variability between cellular populations [35]. The dynamic numerical and structural chromosomal aberrations (genome chaos) result in profound alterations in gene expression, reprogramming of metabolic and signaling pathways and the generation of biochemical/phenotype diversification of cancer cells. Long-term drug-treated cells demonstrate transcriptomic and proteomic changes, and differ from parental cells at the molecular and cellular levels [26, 30]. Despite extensive studies, the role of CIN in the generation of TMZ-driven phenotype diversity and TMZ-based therapeutic failure has been poorly addressed.

Here, we characterized the genome-phenotype evolution of long-term TMZ-treated glioblastoma cell lines. TMZ treatment influenced genomic stability and phenotype diversity in a cell type-dependent manner by selecting resistant genotype-phenotype variants or generating

Table 1 Long-term TMZ treatment of tumour cells results in versatile phenotype responses

\begin{tabular}{|c|c|c|c|c|c|c|c|}
\hline Cell line & Morphology & $\begin{array}{l}\text { Proliferation/ } \\
\text { viability }\end{array}$ & $\begin{array}{l}\text { Cell cycle } \\
\text { distribution }\end{array}$ & $\begin{array}{l}\text { Migration/ } \\
\text { invasion }\end{array}$ & $\begin{array}{l}\text { Growth in } \\
\text { vivo/soft agar }\end{array}$ & $\begin{array}{l}\text { Concentration/ } \\
\text { treatment period }\end{array}$ & Refs \\
\hline A172 & No change & & & & & $100 \mu \mathrm{M} / 1 \mathrm{mo}$ & {$[62]$} \\
\hline $\mathrm{C} 6$ & No change & $\downarrow$ & & $\downarrow$ & $\downarrow$ in soft agar & $\begin{array}{l}100 \mu \mathrm{MM} / 1 \mathrm{mo} \text { in vitro or } \\
50 \mathrm{mg} / \mathrm{kg} / 10 \text { injections } \\
\text { in vivo }\end{array}$ & $\begin{array}{l}\text { this } \\
\text { study }\end{array}$ \\
\hline D54 & Changed & $\downarrow$ & $\begin{array}{l}\uparrow \mathrm{G} 0 / \mathrm{G} 1 \\
\downarrow \mathrm{G} 2 / \mathrm{M}\end{array}$ & $\uparrow$ & & $\begin{array}{l}\text { up to } 0.5 \mathrm{mM} / \\
5 \text { or } 10 \mathrm{mo}\end{array}$ & {$[14]$} \\
\hline CSC & & $\downarrow$ & & & $\downarrow$ in vivo & & {$[10]$} \\
\hline $\begin{array}{l}\text { HEK293 } \\
\text { derivatives }\end{array}$ & No change & $\downarrow$ & & & $\downarrow$ in soft agar & $\begin{array}{l}\text { up to } 120 \mu \mathrm{M} / \\
3 \mathrm{mo}\end{array}$ & {$[23]$} \\
\hline $\begin{array}{l}\text { HeLa } \\
\text { derivatives }\end{array}$ & No change & No change or $\uparrow$ & & & $\uparrow$ in soft agar & $\begin{array}{l}\text { up to } 120 \mu \mathrm{M} / \\
3 \mathrm{mo}\end{array}$ & {$[23]$} \\
\hline Hs683 & & $\downarrow$ & & $\downarrow$ & $\downarrow$ in vivo & $\begin{array}{l}\text { up to } 1 \mathrm{mM} / \\
10 \mathrm{mo}\end{array}$ & {$[8]$} \\
\hline $\begin{array}{l}\text { LN-308, LNT-229, } \\
\text { LN-18 }\end{array}$ & No change & $\downarrow$ & No change & & & up to $\mathrm{EC}_{50} / 6 \mathrm{mo}$ & {$[7]$} \\
\hline T98G & & $\downarrow$ & & No change & No change in vivo & up to $1 \mathrm{mM}$ & {$[19]$} \\
\hline T98G & No change & No change & & No change & $\uparrow$ in soft agar & $100 \mu \mathrm{M} / 1 \mathrm{mo}$ & $\begin{array}{l}\text { this } \\
\text { study }\end{array}$ \\
\hline U87 & Changed & & & $\uparrow$ & & up to $I C_{50}=150 \mu \mathrm{M} / 3$ weeks & {$[18]$} \\
\hline U251 & & & $\uparrow \mathrm{G} 2 / \mathrm{M}$ & & & & {$[21]$} \\
\hline U251 & No change & $\downarrow$ or $\uparrow$ & & $\downarrow$ or $\uparrow$ & $\begin{array}{l}\text { No change in soft } \\
\text { agar }\end{array}$ & $\begin{array}{l}\text { up to } 100 \mu \mathrm{M} / \\
5 \text { or } 10 \text { weeks }\end{array}$ & $\begin{array}{l}\text { this } \\
\text { study }\end{array}$ \\
\hline U373 & & $\uparrow$ & & $\uparrow$ & $\uparrow$ in vivo & up to $1 \mathrm{mM}$ & [19] \\
\hline
\end{tabular}


novel versatile phenotypes by promoting CIN. Our data indicate that in addition to the reported TMZ-driven hypermutation phenotype [36-38], TMZ-instigated changes in genome stability and heterogeneity may contribute to the versatile phenotypic responses of tumour cells.

\section{Results \\ Temozolomide promotes polyploidization and diverse karyotype changes}

To reveal the TMZ-promoted karyotypic and phenotypic changes, U251TMZ1, U251TMZ2, T98GTMZ, and C6TMZ cells were derived by repetitively exposing U251, T98G and C6 cells to TMZ $(100 \mu \mathrm{M})$ in vitro, whereas C6R1 and C6R2TMZ cells were established in vivo [50 mg/kg, 10 intraperitoneal (i.p.) injections]. The vehicle-treated U251 cells were predominantly hyperdiploid with the mean number of chromosomes $53 \pm 9.2 ; 11 \%$ of cells contained more than 60 chromosomes/cell and $4.5 \%$ of cells had more than 90 chromosomes/cell (calculated from 200 metaphases). In contrast, U251TMZ1 cells were mainly hypertetraploid with the mean number of chromosomes $100 \pm 8.2$ (90\%). The U251TMZ2 cells consisted of two subpopulations: a predominant subpopulation with a hyperdiploid karyotype (53.9 \pm 7.5 ; $60 \%)$ and a subpopulation with a hypertetraploid karyotype $(108.2 \pm 13.4 ; 27 \%)$. A total portion of U251TMZ2 cells with more than 60 chromosomes/cell increased up to $40 \%$ (Fig. 1a, b).

It was reported [11] that TMZ-resistant lines derived from a hyperdiploid SNB19 cell line (which is itself a derivative of U251 cells [23]) had deviations from a parental modal chromosome number or ploidy change, however, no analysis of CIN was performed. To visualize and compare CIN between cell lines, we used karyographs, 3-dimensional graphs, where $\mathrm{x}$-axis designates the normal and aberrant chromosomes (clonal and non-clonal chromosome aberrations (CCAs/NCCAs), $\mathrm{y}$-axis - the chromosome copy numbers, and z-axis-the numbers of metaphases arrayed for comparison to each other [33]. The karyographs show the degree of clonality and variability of chromosomes between individual cells of a cell line by comparing the copy numbers of intact and abnormal chromosomes of metaphases to each other. The karyotype differences between cell lines were demonstrated by alignment and comparison of karyographs of vehicle- and TMZ-treated derivatives. Karyotype changes of U251TMZ1 cells were accompanied by a loss of 5 CCAs, an acquisition of 21 new CCAs and a higher total number, frequency and per cell variation of NCCAs. Karyotype changes of U251TMZ2 hyperdiploid subpopulation were a loss of 5 and a gain of 8 new CCAs with an increase in the total number and per cell variation of
NCCAs, whereas polyploid subpopulation was characterized by a loss of 4 and an acquisition of 17 new CCAs with an increase in the total number and per cell variation of NCCAs (Fig. 1c, d; Additional file 1: Table S1). Many CCAs were distinct between U251TMZ1 and U251TMZ2 cells. Analysis of array comparative genome hybridization $(\mathrm{aCGH})$ data revealed striking differences in copy number alterations (CNAs) between U251, U251TMZ1 and U251TMZ2 cells (Fig. 1e; Additional file 2: Table S2).

Both T98G and T98GTMZ cells had a near-pentaploid karyotype with the mean numbers of chromosomes $121.5 \pm 8.7$ and $120 \pm 8.3$, respectively. Karyotype changes of T98GTMZ cells were accompanied by a loss of 13 CCAs, an acquisition of 20 new CCAs and a higher total number, frequency and per cell variation of NCCAs (Fig. 2a, b; Additional file 3: Table S3). The most obvious differences of CNAs between T98GTMZ and T98G cells were a loss of 4p15.2-p14 and 10p15.3-p11.21 in T98GTMZ cells and a gain of 2q37.1-q37.3, 5q35.1-q35.3, 6p22.1-p21.31, 17q25.1q25.3, and a loss of 18q11.2-q12.1 in T98G cells (Fig. 2c; Additional file 4: Table S4).

A morphometric analysis of C6R1 and C6R2TMZ glioma volume after 2 weeks of i.p. injection of DMSO or TMZ showed apparent differences in growth $(\approx 75$ versus $\approx 30 \mathrm{~mm}^{3}$ ) (Fig. 3a). C6TMZ, C6R1 and C6R2TMZ cells were near-diploid with the mean chromosome numbers 40-41 ( $\pm 4.1-7.1)$ (Fig. 3b, c) and presented the selected subclones of karyotypically heterogeneous C6 cell line. Karyotype changes of C6TMZ cells and to a larger extent of C6R2TMZ cells were characterized by a reduction of a total number of CCAs and NCCAs. Interestingly, C6R1 also demonstrated a reduction of a total number of CCAs and NCCAs, suggesting that in vivo TMZ-treated cells underwent a two-stage selection: by the rat brain microenvironment and TMZ treatment (Fig. 3d, e; Additional file 5: Table S5). The major aberrations detected by aCGH and shared by $\mathrm{C} 6$ derivatives were a gain of 7p21.1-q31.1 and a loss of 16q12.1-q24.3. Additionally, C6TMZ but not C6R2TMZ cells demonstrated a gain of 4p16.1-q26 (Fig. 3f; Additional file 6: Table S6). Using the DAVID bioinformatics resource [39], a list of 613 well-annotated genes in this region was retrieved (Additional file 7: Table S7a). We also manually curated a list of published proteins/miRNAs that were shown to contribute to TMZ resistance (Additional file 8: Table S8). Then we cross-checked both lists and revealed at least 15 hits (marked in Additional file 7: Table S7a). Cross-checking with a list of 1221 putative genes extracted from the NCBI Map Viewer for the chromosomal region of interest produced several additional hits (marked in Additional file 7: Table S7B). Thus, TMZ treatment in vitro favoured selection of cells with a gain 


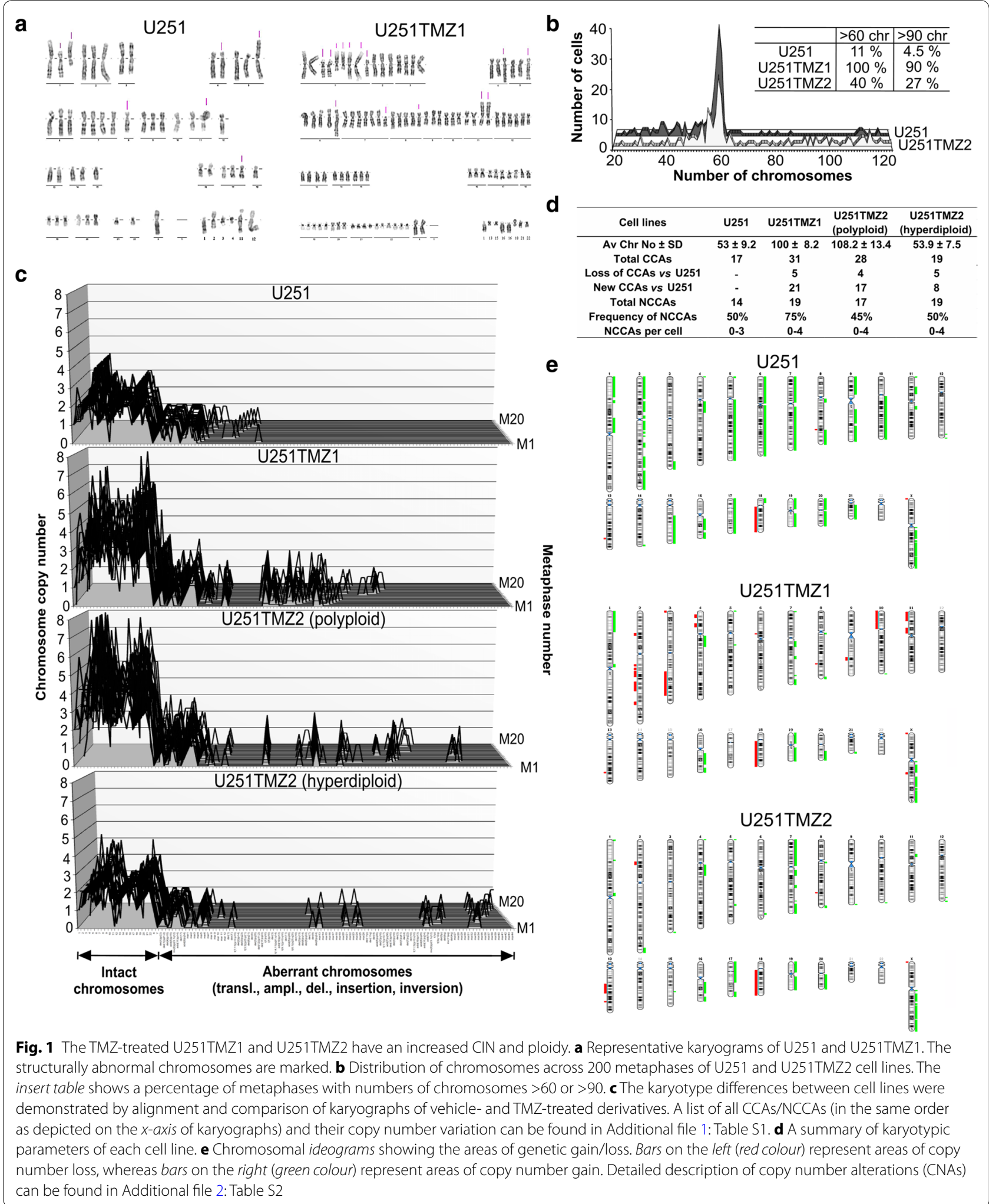

of the chromosomal region enriched in genes conferring resistance to TMZ. Copy number gain of the 4p16.1q26 region in only in vitro TMZ-treated C6 cells may potentially result from a different TMZ concentration as well as in vitro versus in vivo cytotoxic effects. Firstly, tumour $\mathrm{TMZ} \mathrm{C}_{\max }$ varied at $20.6 \pm 13.4 \mu \mathrm{M} / \mathrm{L}$ across 


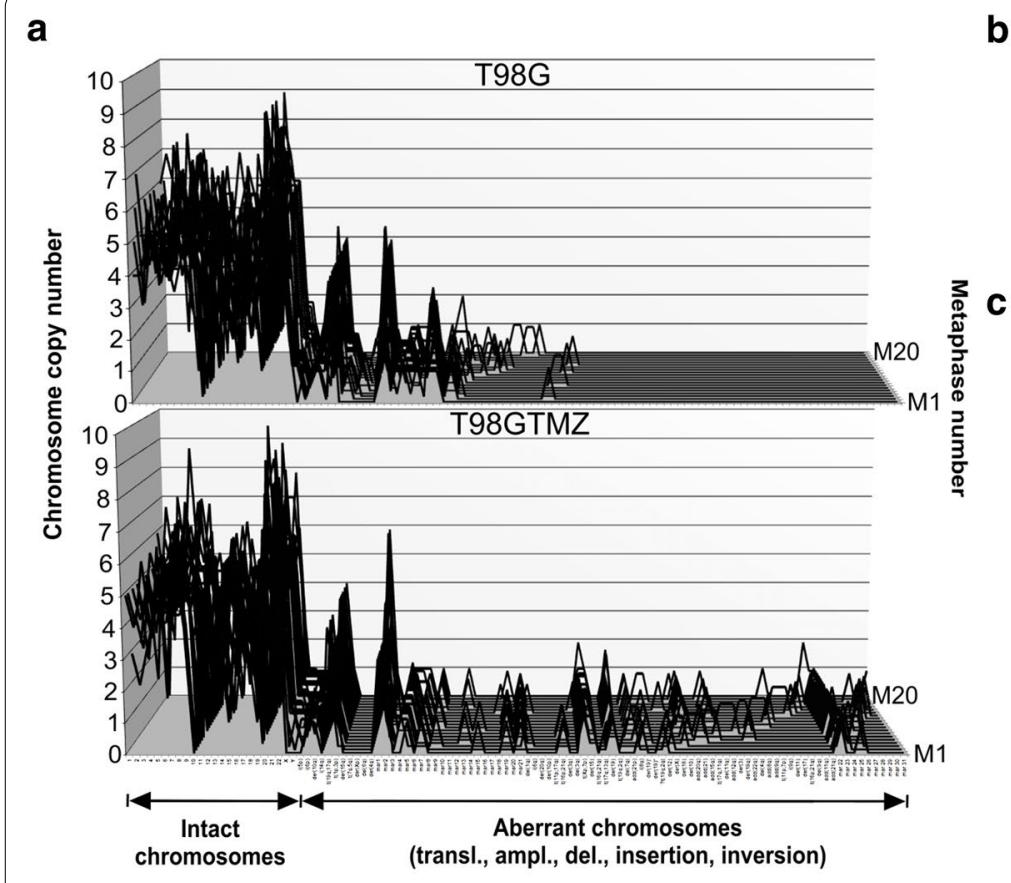

b

\begin{tabular}{ccc}
\hline Cell lines & T98G & T98GTMZ \\
\hline Av Chr No \pm SD & $121.5 \pm 8.7$ & $120 \pm 8.3$ \\
Total CCAs & 27 & 39 \\
Loss of CCAs vs T98G & - & 13 \\
New CCAs vs T98G & - & 20 \\
Total NCCAs & 13 & 27 \\
Frequency of NCCAs & $45 \%$ & $75 \%$ \\
NCCAs per cell & $0-3$ & $0-4$ \\
\hline
\end{tabular}
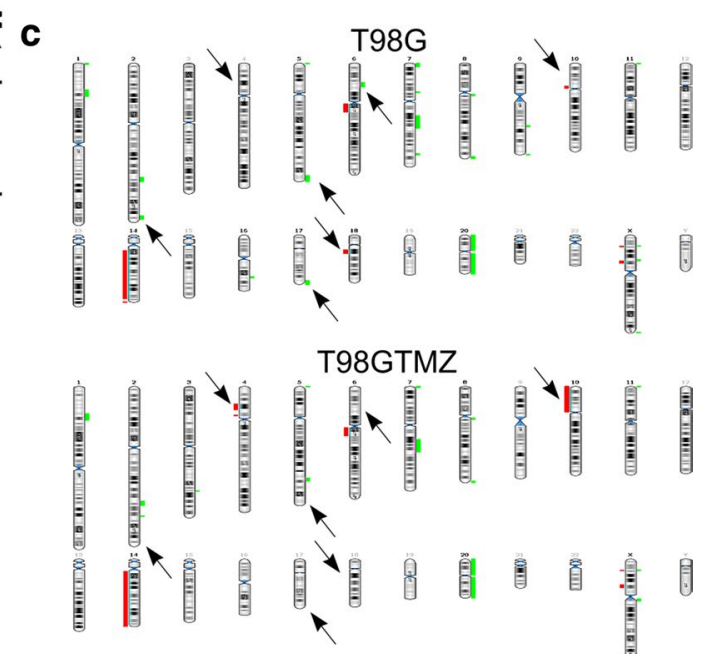

Fig. 2 The TMZ-treated T98GTMZ have an increased CIN. a The karyotype differences between cell lines were demonstrated by alignment and comparison of karyographs of vehicle- and TMZ-treated derivatives. A list of all CCAs/NCCAs (in the same order as depicted on the $x$-axis of karyographs) and their copy number variation can be found in Additional file 3: Table S3. b A summary of karyotypic parameters of each cell line. c Chromosomal ideograms showing the areas of genetic gain/loss. Bars on the left (red colour) represent areas of copy number loss, whereas bars on the right (green colour) represent areas of copy number gain. Arrows depict the most obvious copy number alteration (CNA) differences between cell lines. Detailed description of copy number alterations (CNAs) can be found in Additional file 4: Table S4

glioma bearing rats after $20 \mathrm{mg} / \mathrm{kg}$ intra-venous (i.v.) injections [40]. Hence TMZ tumour concentration following $50 \mathrm{mg} / \mathrm{kg}$ i.p. injections, a dose used in this study, should still be lower than that used in culture $(100 \mu \mathrm{M})$. Secondly, we and others demonstrated the formation in vivo of connexin 43-mediated gap junction channels between glioma cells and astroglia [41, 42]; this communication significantly reduces TMZ cytotoxicity [43].

\section{Temozolomide promotes versatile phenotype changes}

To elucidate how TMZ affected oncogenic characteristics of cells, we first analyzed cell proliferation. Previous studies demonstrated that the proliferation of long-term TMZ-treated glioblastoma cells was increased, decreased or unchanged (Table 1). U251 cells proliferated faster than U251TMZ1 cells but slower than U251TMZ2 cells. No difference in proliferation between T98G and T98GTMZ cells was observed. C6TMZ and C6R2TMZ cells proliferated slower than C6 and C6R1 cells, respectively. Furthermore, C6R1 and C6R2TMZ cells proliferated slower than C6 and C6TMZ cells, respectively (Fig. 4a), suggesting that the rat brain microenvironment might preferentially select for slower-dividing C6 cells.
On the other hand, in vivo grown C6 derivatives, adapted for the different metabolic and growth-stimulating microenvironment within the brain, may undergo stress, when reintroduced to an in vitro culture. Additionally, we cannot exclude an effect of DMSO as it induced cytotoxicity at certain concentrations in vivo [44]. However, much lower DMSO concentration/volume $(20 \% / 200 \mu \mathrm{l})$ was injected during this study than was previously reported in ([44] and refs therein).

Previous studies showed that TMZ or radiotherapy with TMZ treatment of glioblastoma cells was associated with a reduced glucose uptake [10, 22]. To test the sensitivity of cell growth to a glucose concentration reduction, proliferation was analyzed in low-glucose medium ( $1 \mathrm{~g} / \mathrm{L}$ glucose) and compared to high-glucose medium (4.5 g/L glucose). Proliferation of U251cells did not change, was slightly increased for U251TMZ1 cells but reduced for U251TMZ2 cells. Furthermore, in contrast to high-glucose medium, no significant difference in proliferation was observed between U251, U251TMZ1 and U251TMZ2 cells in low-glucose medium (Fig. 4b). Both T98G and T98GTMZ cells were highly sensitive to a reduction in glucose concentration, demonstrating 


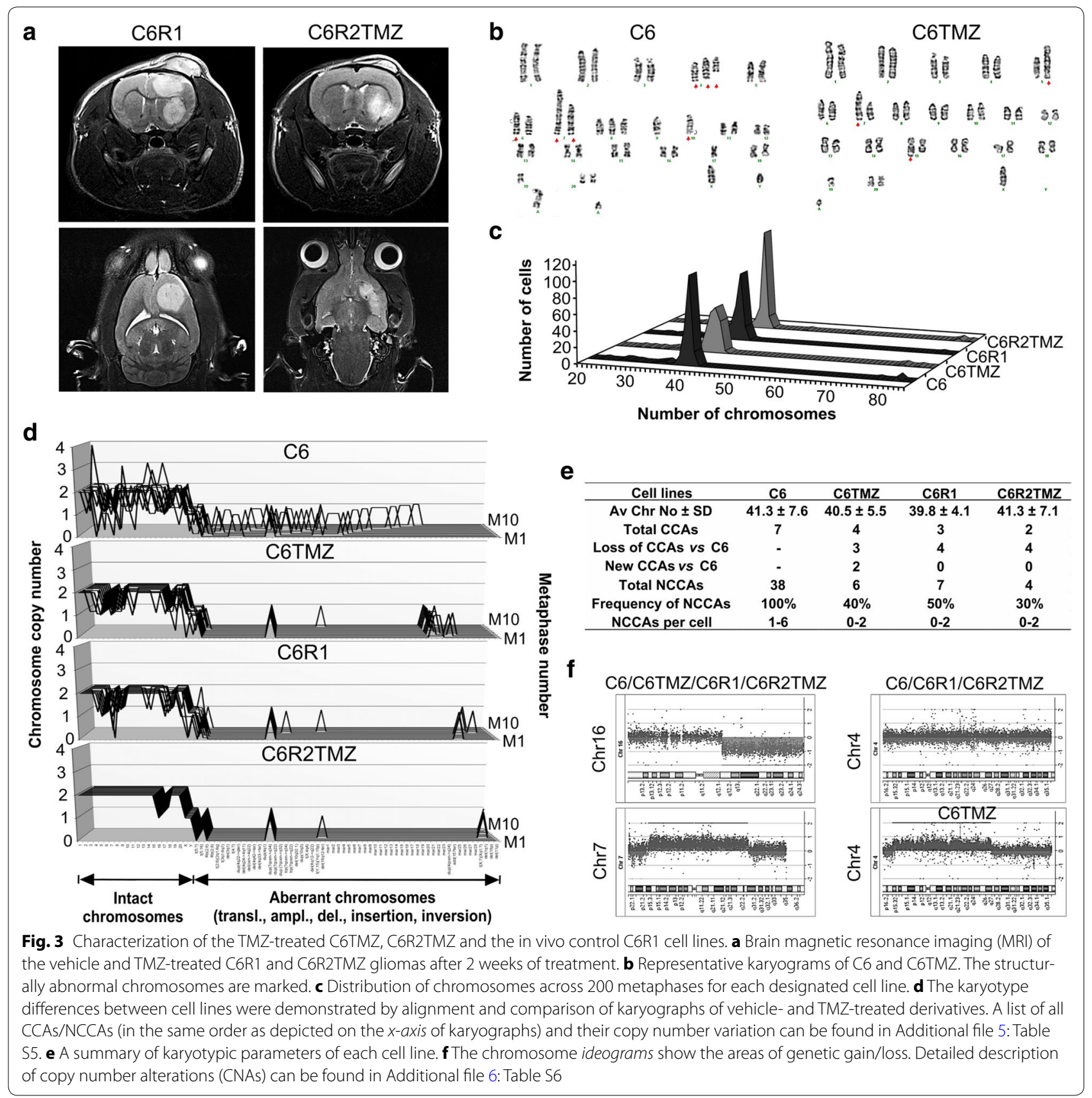

significantly inhibited, comparable growth. Proliferation of $\mathrm{C6}$ cells was also reduced in low-glucose medium, whereas no change in proliferation was detected for C6TMZ, C6R1 and C6R2TMZ cells (Fig. 4b). Significantly, C6TMZ and C6R1 cells proliferated faster than C6 cells in low-glucose medium, whereas proliferation of $\mathrm{C} 6$ and C6R2TMZ cells was comparable (Fig. 4b).

An analysis of colony formation efficiency showed no significant difference between U251 and U251TMZ1 or
U251TMZ2 cells; however, U251TMZ2 cells formed more colonies than U251TMZ1 cells. T98GTMZ cells formed more colonies than T98G cells, whereas C6TMZ and C6R2TMZ cells formed a fewer number of colonies than C6 and C6R1 cells, respectively (Fig. 4c). This is in agreement with the previous studies where it was demonstrated that colony formation efficiency or growth in vivo of long-term TMZ-treated cells was increased, decreased or unchanged (Table 1). 


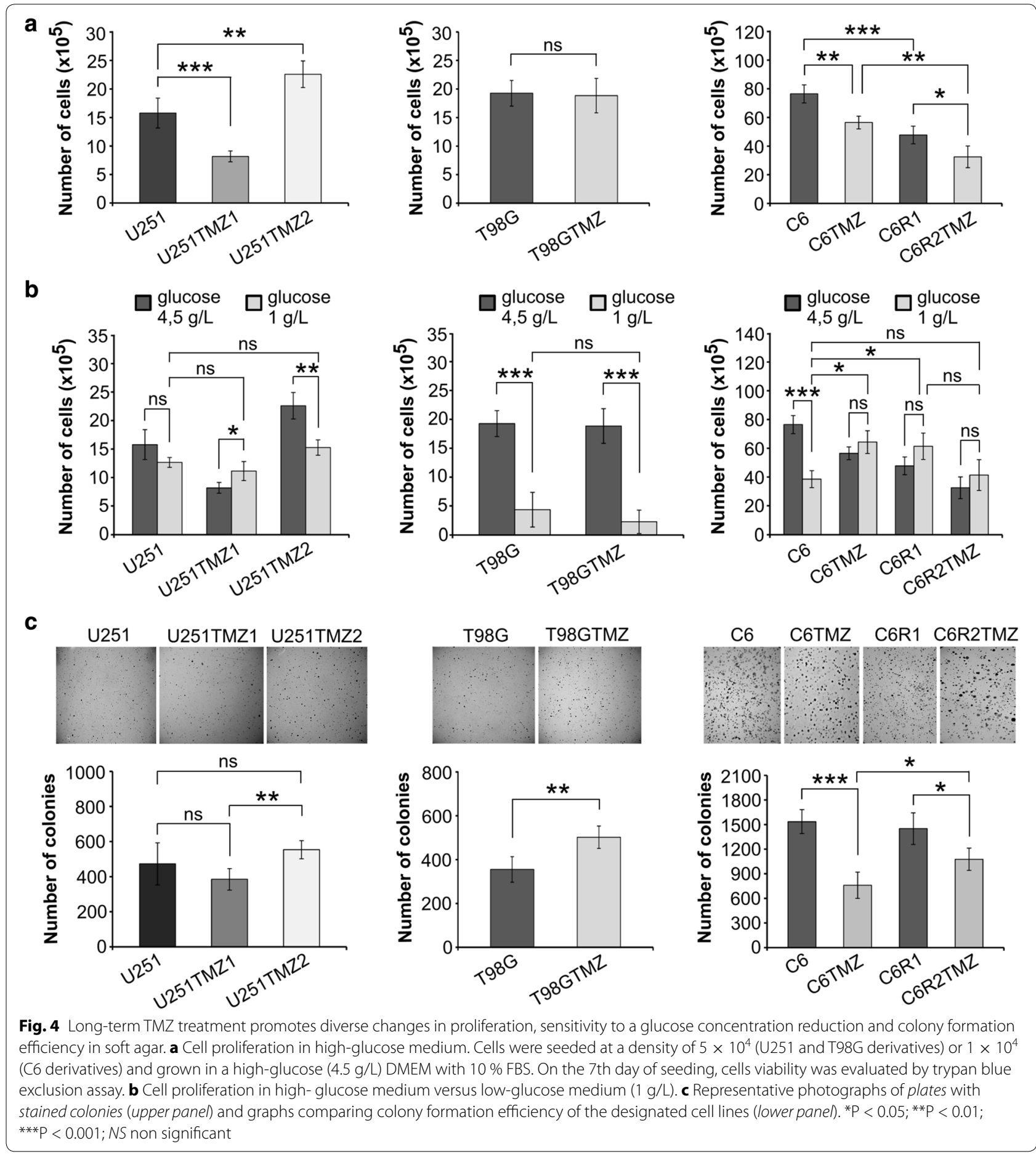

U251TMZ1 cells migrated faster than U251 cells but no difference in migration was observed between U251 and U251TMZ2 cells (Fig. 5a). Furthermore, no difference in migration was detected between T98G and T98GTMZ cells, whereas C6TMZ and C6R2TMZ cells migrated slower than C6 and C6R1 cells, respectively. In contrast to a migration analysis, transwell invasion assay demonstrated a lower and higher invasion rate of U251TMZ1 and U251TMZ2 cells, respectively (Fig. 5b). Similar to a migration analysis, no difference in invasion 


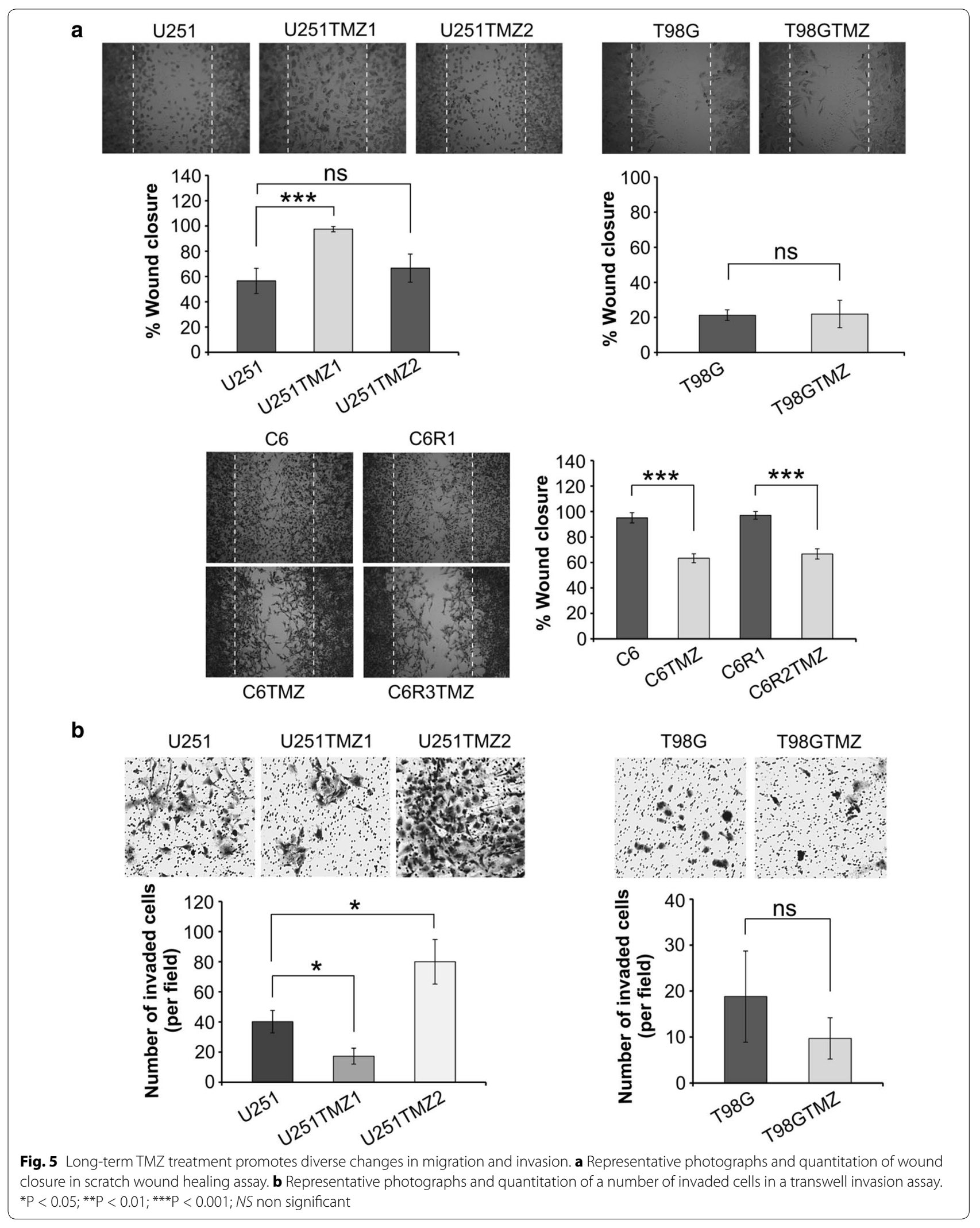


rate was observed between T98G and T98GTMZ cells. Similar results were obtained in the previous studies where migration or invasion of long-term TMZ-treated cells was found to be increased, decreased or unaffected (Table 1).

Quantitative real time PCR (qRT-PCR) analysis of the expression of stem cell markers CD133, OCT4, SOX2 and NANOG showed more than a twofold up-regulation of only CD133 in U251TMZ1 and U251TMZ2 cells, whereas more than a twofold down-regulation of $C D 133$ was observed in T98GTMZ cells, OCT4 in T98GTMZ cells, and SOX2 in U251TMZ1 cells (Additional file 9: Figure S1a).

The TMZ-treated cell lines had individual patterns in expression/activation of signal transduction proteins (Fig. 6). An analysis of epithelial-mesenchymal transition (EMT) markers showed increased expression of Vimentin, Slug and Claudin-1 in U251TMZ2 cells and Vimentin in U251TMZ1 cells. No significant changes in EMT markers expression were revealed between T98G and T98GTMZ cells. U251TMZ2 but not U251TMZ1 cells had increased expression of MDM2. In contrast, U251TMZ1 but not U251TMZ2 cells had increased pAKT1, pERK1/2, and ASK1. T98GTMZ cells had increased pAKT1, pERK but not ASK1 and MDM2. Both U251TMZ1 and U251TMZ2 cells but not T98GTMZ cells had increased total and phosphorylated p53 levels. T98GTMZ cells but not U251TMZ1 or U251TMZ2 cells expressed MGMT. In addition, no MGMT expression in U251, U251TMZ1 or U251TMZ2 cells was detected by qRT-PCR (Additional file 9: Figure S1b). No PARP expression changes or cleavage was observed. If we extrapolate this low-scale Western blot analysis data on the whole (phospho)proteome, a striking difference and individuality of each TMZ-treated cell line in comparison to control cells would be revealed as it was demonstrated previously [13-15].

Finally, we analyzed whether the TMZ-treated cells changed sensitivity to TMZ re-challenge. U251TMZ1 and U251TMZ2 cells were less responsive to $20 \mu \mathrm{M}$ TMZ. T98GTMZ but not T98G cells grew slightly faster in the presence of $20 \mu \mathrm{M} \mathrm{TMZ}$, whereas their growth was comparably inhibited by $100 \mu \mathrm{M}$ TMZ. Proliferation of C6 cells was significantly inhibited by 20 or $100 \mu \mathrm{M}$ TMZ, whereas the relative ratios of growth inhibition after TMZ re-challenge of $\mathrm{C} 6$ derivatives were C6 > C6R1 > C6TMZ $\approx$ C6R2TMZ (Fig. 7a). All cell lines were highly sensitive to $2 \mu \mathrm{M}$ temsirolimus (TEM, mTOR kinase inhibitor) with no changes in the sensitivity after long-term TMZ treatment (Fig. 7b). $5 \mu \mathrm{M}$ U0126 (an extensively studied experimental MEK1/2 inhibitor

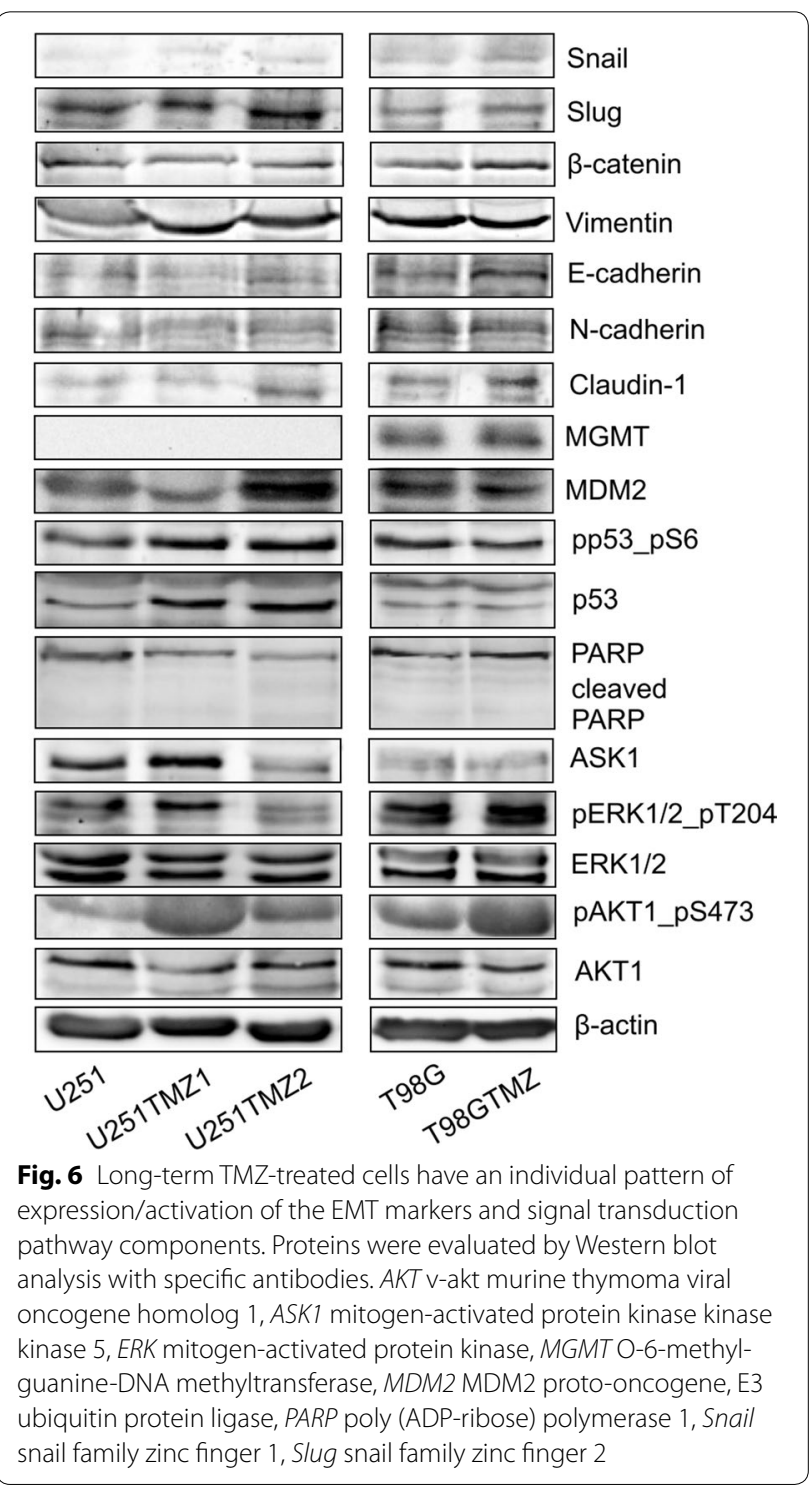

[45]) inhibited proliferation of U251TMZ2 but not U251 or U251TMZ1 cells. Proliferation of both T98G and T98GTMZ cells was insensitive to U0126. In contrast, C6 derivatives were highly sensitive to U0126 with no change in response after TMZ treatment (Fig. 7c).

\section{Discussion}

In this study we characterized genome-phenotype changes of long-term TMZ-treated glioblastoma cell lines and found that TMZ may either increase or reduce genomic diversity (CCA/NCCAs) and tumour cell aggressiveness. An increase of resistance to TMZ rechallenge seems to be the only fundamental common 


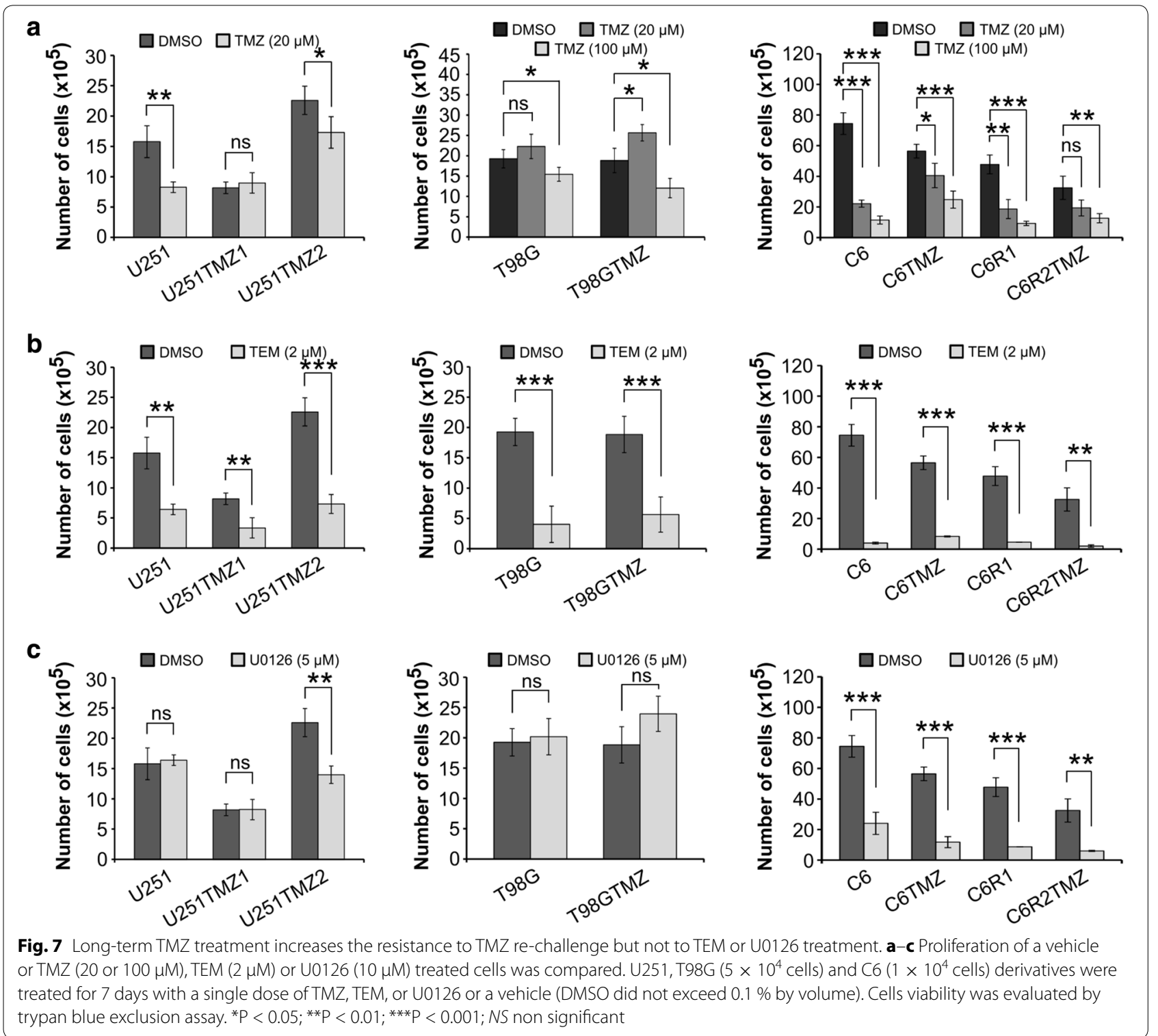

and predictable trait intrinsic to all long-term TMZtreated cells; all other phenotype responses were versatile (Table 1). Our data indicate that changes in genome stability and diversity may be responsible for individual and heterogeneous phenotypes of long-term TMZ-treated cells. It is worth emphasizing that U251TMZ1 and U251TMZ2 cell lines, established by parallel selection of the same parental cell line with the same chemotherapy agent under similar treatment conditions with the only difference in the duration of treatment (10 versus 5 weeks), underwent individual genomic and phenotypic evolution. The development of a heterogeneous range of drug-resistant lines with individual genomic and/or phenotypic changes from the same cell line, treated with the same chemotherapy agent (e.g., cisplatin, puromycin) was reported previously $[3,31]$.

The therapy-driven glioblastoma genome evolution was scarcely reported previously. An analysis of primary cell cultures established from three surgery glioblastoma specimens of the same patient (primary specimen and two consecutive recurrences after lomustine and TMZ therapy) demonstrated a distinct subclonal architecture, abnormalities in karyotypic pattern, and rates of proliferation and migration [46]. Extending research on additional matched primary and recurrent glioblastomas, authors revealed that therapy either increased 
chromosomal aberrations in some cases that correlated with relatively short overall survival or reduced genome diversity in other cases and these patients showed a much longer overall survival [46]. Recent sequencing of primary and TMZ-treated recurrent gliomas showed the TMZ-driven amplification of mutation heterogeneity (hypermutation phenotype) in IDH1-mutant but not IDH1-wild-type astrocytic gliomas [36-38]. High levels of MGMT methylation and intrinsic or acquired mutations in the key MMR genes and/or MGMT were associated with hypermutation phenotype [36]. However, these studies were primarily focused on alterations in DNA sequence rather than on CIN.

The resistance acquisition to TMZ was widely attributed to $\mathrm{O}^{6}$-methylguanine-DNA methyltransferase (MGMT). Despite a relatively low proportion of the TMZ-driven cytotoxic $\mathrm{O}^{6}$-methylguanine lesion formation (5\%), the methylated promoter of $M G M T$ was considered one of the most robust predictor of TMZ response with inverse correlation [47, 48]. However, this generally good correlation between MGMT methylation and TMZ treatment response was recently challenged. The TCGA Research Network reported that MGMT promoter methylation could serve as a predictive biomarker only in the glioblastoma classical subtype but not in the other subtypes (mesenchymal, proneural or neural) [49]. Moreover, clonal analysis of glioblastoma samples demonstrated inter-tumor variability in $M G M T$ promoter methylation and MGMT protein expression levels, which were inconsistent with TMZ responses [6]. Similarly, no correlation between the TMZ sensitivity and MGMT promoter methylation, mRNA or protein expression was revealed for eleven diffuse large B cell lymphoma cell lines [4]. Here we found that long-term TMZ-treated cells reduced sensitivity to TMZ re-challenge without changing MGMT mRNA or protein expression levels. On the other hand, previous reports based on transcriptome analysis elucidated that complex individual genetic networks rather than a specific common mechanism conferred a different TMZ sensitivity [4]. Furthermore, the TMZ-resistant variants of Hs683, U87, and LNZ308 cell lines demonstrated individuality in global miRNA expression, and the integrative miRNA/mRNA network analysis revealed obvious differences in the genetic network in comparison to control cells [12]. A measurement of global kinase activity of five TMZ resistant cell lines revealed no common kinase-driven pathway of TMZ resistance, and two TMZ resistant lines demonstrated extreme kinomic activity differences in comparison to control cells [15]. Altogether, adaptation of tumour cells to long-term TMZ cytotoxicity and genotoxicity is associated with profound diverse changes in the transcriptome, proteome, kinome and metabolome [8-15], the versatile phenotype responses (Table 1), involvement of many proteins/miRNAs (Additional file 8: Table S8) (see also the recent large synthetic lethal screens for "TMZsensitizing genes") $[9,50]$ and DNA repair pathways [51].

The cancer stem cell hypothesis postulates a significant role of glioblastoma cancer stem cells (GSC) in therapy resistance and tumour recurrence. However, a recent study showed that clones of GSC had distinct tumourigenic potential that was determined by their genetic diversity rather than expression levels of different GSCassociated markers (CD133, CD15, A2B5 or CD44) [52]. Moreover, although TMZ treatment induced conversion of non-GSC into GSC both in vitro and in vivo [53], the majority of patient-matched GSC and non-GSC cultures (25 tested) had a similar TMZ responsiveness and in some cases GSC were even more sensitive [54]. These studies highlight the primary importance of genetic heterogeneity in tumorigenic potential of CSC-associated populations, and furthermore point to dynamic plasticity of tumor cells under TMZ therapy and no superiority of GSC over bulk tumor population in TMZ resistance.

There are approximately twenty current clinical studies using mTOR inhibitors for the treatment of gliomas [55]. However, phase II studies with recurrent glioblastoma reported no efficacy of TEM in the combination with TMZ, sorafenib, bevacizumab, or erlotinib [55]. Although we used a clinically relevant TEM concentration [56], the discrepancy between cell culture responses (Fig. 7b) and patient responses is obvious. It is worth noting that TEM is also able to induce/promote CIN in tumor and normal cells [57]. A targeted therapy failure in patients with recurrent glioblastoma after radiotherapy with TMZ [58] highlights the necessity to lower the evolutionary potential of a tumour and constrain its dynamics by directing efforts at reducing tumour population diversity, at potentiating the immune system and homeostasis of the individual.

In conclusion, our current data improve the knowledge on the TMZ-instigated genome evolution and highlight the primary importance of genetic instability in chemotherapy failure as the more different combinations of molecular mechanisms exist within a cancer cell population, the more likely a population adapts to drug cytotoxicity/genotoxicity. TMZ treatment-associated changes of the genetic network (gene content, RNA and protein expression and their interaction), which are governed by changes of the genome context (number and structure of chromosomes and their nuclear topology) may offer an explanation for why the versatile and opposite phenotype responses of long-term TMZ treated tumor cells were observed in different studies (Table 1). Although our study is limited to the use of established glioblastoma cell lines, our results are consistent with a recent 
report on evolution of low-grade gliomas to aggressive high-grade glioblastoma in 6 of 10 patient cases due to an increased mutation load upon TMZ therapy [38]. Our results and the latter study suggest that the therapeutic promotion of excessive genetic instability/heterogeneity is a double-edged sword: while the primary response in the form of increased overall survival will be positive, the price for moderate inhibition of tumour growth will be changes in the genomic landscape, tumour subclonal architecture, and, eventually, promotion of cancer evolution, which ultimately impacts the therapeutic management of recurrence.

\section{Methods}

\section{Cell cultures}

Human U251 (Bank of Cell Lines from Human and Animal Tissues, R.E. Kavetsky Institute of Experimental Pathology, Oncology and Radiobiology, Kyiv, Ukraine), T98G (ATCC) and rat C6 (Pirogov Russian State Medical University, Moscow, Russia) glioma cell lines were grown in DMEM (HyClone, Thermo Scientific, UK) supplemented with $10 \%$ fetal bovine serum (FBS, HyClone) and $100 \mu \mathrm{g} / \mathrm{ml}$ penicillin $/ 100 \mathrm{u} / \mathrm{ml}$ streptomycin (Sigma, USA) in an environment of $95 \%$ air $/ 5 \%$ CO2. U251, T98G, and C6 cell lines are isocitrate dehydrogenase 1 (IDH1)-wild-type. U251 is MGMT-negative; T98G is MGMT-positive.

\section{Pharmacological agents}

Temozolomide (TMZ, Sigma), Temsirolimus (TEM, Abcam Biochemicals, USA) and U0126 (Abcam Biochemicals) were dissolved in DMSO to a concentration of $100 \mathrm{mM}$. The final DMSO concentration in the culture medium did not exceed $0.4 \%$. Stock solutions of all drugs were stored at $-20^{\circ} \mathrm{C}$.

\section{TMZ treatment of glioblastoma cells in vitro}

U251, T98G, and C6 glioblastoma cell lines were treated with DMSO or TMZ (Sigma) twice with $25 \mu \mathrm{M}$, twice with $50 \mu \mathrm{M}$ and then with $100 \mu \mathrm{M}$ TMZ twice per week during 5 weeks (U251TMZ2, T98GTMZ and C6TMZ) or 10 weeks (U251TMZ1), followed by several weeks of washout (in the TMZ-free medium) before in vitro tests. DMSO did not exceed $0.1 \%$ of the culture medium.

\section{TMZ treatment of $\mathrm{C} 6$ cells in vivo}

The animals were kept in accordance with the Guidelines on Laboratory Practices adopted by the Ministry of Health of the Russian Federation (Order 267, 19 June 2003). The protocol stipulating animal treatment was approved by the Ethics Committee of N. I. Pirogov
Russian State Medical University, and all rules and regulations were followed during experimentation on animals. Glioma modeling was performed by the intracerebral stereotactic implantation (Leica stereotactic device, USA) of C6 cells $\left(5 \times 10^{5}\right)$ into the striatum region of ketamineanesthetized adult female Wistar rats as described previously [59]. Rats with C6 glioma received $20 \%$ DMSO $(\mathrm{n}=1, \mathrm{C} 6 \mathrm{R} 1)$ or TMZ $(\mathrm{n}=1$, C6R2TMZ) injected intraperitoneally (i.p.) three times per week at a dose of $50 \mathrm{mg} / \mathrm{kg}$. Rats were sacrificed after 10 injections. Gliomas were aseptically harvested, mechanically disaggregated, and a cell suspension was seeded into adherent dishes. Cells were used at the passages 3-10 for analysis.

\section{Conventional cytogenetics}

Chromosome samples were prepared as described previously [23]. 200 metaphase plates were calculated for distribution of chromosome across cells. 20 metaphases (U251 and T98G derivatives) or 10 metaphases (C6 derivatives) were described for chromosome abnormalities, according to the International System for Human Cytogenetic Nomenclature (ISCN 2013). Clonal chromosome aberrations (CCAs) were defined as aberrations found at least in two cells among examined metaphases, whereas non-CCAs (NCCAs) as aberrations detected in only one cell. The frequency of NCCAs in a cell line was calculated by dividing the number of metaphases displaying NCCAs to the total number of examined metaphases $(\times 100 \%)$. Only structural NCCAs were considered.

\section{Array comparative genome hybridization (aCGH)}

A total DNA was isolated using NucleoSpin Blood DNA extraction kit (Macherey-Nagel, Germany) according to the manufacturer's instructions. To analyze copy number alterations (CNAs), aCGH was performed as detailed previously [23]. Human and rat cell lines were analyzed on the CytoSure Aneuploidy Array 15 k (Oxford Gene Technologies, UK) and $180 \mathrm{~K}$ microarrays (Agilent Technologies, USA), respectively. Image analysis of human and rat samples was carried out with CytoSure Analysis Software (Oxford Gene Technologies) and Agilent CytoGenomics Edition 2.9.2.4, respectively.

\section{Cell proliferation in a high and low-glucose medium}

Cells were seeded onto $6 \mathrm{~cm}$ dishes at a density of $5 \times 10^{4}$ (U251 and T98G derivatives) or $1 \times 10^{4}$ (C6 derivatives) and grown in high-glucose $(4.5 \mathrm{~g} / \mathrm{L})$ or low-glucose $(1 \mathrm{~g} / \mathrm{L})$ DMEM with $10 \%$ FBS. On the 7 th day of seeding, cells were harvested, incubated with trypan blue, and calculated using hemocytometer. Experiments were repeated at least three times. 


\section{Cell viability test}

U251, T98G $\left(5 \times 10^{4}\right.$ cells $)$ and C6 $\left(1 \times 10^{4}\right.$ cells $)$ derivatives were seeded onto $6 \mathrm{~cm}$ dishes and incubated overnight. The cells were treated for 7 days with a single dose of TMZ (20 and $100 \mu \mathrm{M})$, TEM $(2 \mu \mathrm{M})$, U0126 $(5 \mu \mathrm{M})$ or DMSO. Experiments were repeated at least three times. Cell viability was evaluated by trypan blue exclusion assay instead of metabolically-based MTT or ATP assays, which are prone to over/underestimate cell viability under cytotoxic stress [45].

\section{Soft agar colony formation assay}

$5 \times 10^{3}$ cells were placed in $1.5 \mathrm{ml}$ of $0.35 \%$ low gelling temperature agarose (Gibco, Life Technologies, USA) with DMEM supplemented with $10 \%$ FBS. $0.35 \%$ top agarose was poured on $1.5 \mathrm{ml}$ of solidified $0.5 \%$ base agarose $/ 10 \%$ FBS/DMEM. Cells were seeded in triplicates in a $35-\mathrm{mm}$ dish and grown at $37^{\circ} \mathrm{C}$ for 21 days to allow colony formation. Colonies were visualized by staining with $0.005 \%$ crystal violet, photographed, counted using OpenCFU software [60], and expressed as the means of triplicates of four independent experiments.

\section{Scratch wound healing assay}

Using a P200 pipette tip, the scratches were made by scraping across the confluent cell monolayer. Pictures were taken at 0 and $16 \mathrm{~h}$ (C6 derivatives) or $24 \mathrm{~h}$ (U251 and T98G derivatives) and automated image analysis was carried out using TScratch software [61] to avoid any potential bias in quantifying an extent of migration. At least twelve wound healing areas for each cell line were photographed and analyzed to take into account the differences in cell density and widths of scratches. The per cent of wound area closure was calculated taking open wound area at $0 \mathrm{~h}$ for $100 \%$.

\section{Cell invasion assay}

A 24-well tissue culture plate-based Chemicon cell invasion assay (QCM ECMatrix 550, Millipore, USA) was performed according to the manufacturer's protocol. $2 \times 10^{5}$ cells were seeded to the inserts. After $24 \mathrm{~h}$, five fields of invaded cells in each well were randomly photographed and counted manually. Test was performed two times.

\section{Real time quantitative PCR}

Total RNA was extracted from cell lines using TRI Reagent (Sigma, \#T9424) according to the manufacturer's recommendations. Equal amounts of total RNA $(5 \mu \mathrm{g}$ for $20 \mu$ reaction mixture) were transcribed into cDNA with random hexamer primers and RevertAid Reverse Transcriptase (Thermo Scientific, \#EP0441). Twofold diluted cDNA and gene specific primers were mixed with Maxima SYBR Green qPCR Master Mix (2X) (Fermentas,
\#K0251) according to the manufacturer's recommendations. qRT-PCR was run in triplicates on CFX96 RT-PCR Detection System (Bio-Rad). The amplification procedure of target genes was as follows: initial denaturing step at $95^{\circ} \mathrm{C}$ for $10 \mathrm{~min}$, followed by 40 cycles of denaturation at $95^{\circ} \mathrm{C}$ for $15 \mathrm{~s}$, annealing at $59^{\circ} \mathrm{C}$ for $30 \mathrm{~s}$ and extension at $72{ }^{\circ} \mathrm{C}$ for $30 \mathrm{~s}$. Melting curve analysis was performed to confirm amplification specificity. To calculate the relative gene expression ratios (fold-change), $\mathrm{C}_{\mathrm{T}}$ method (also known as the $2^{-\triangle \Delta C T}$ method, expressed as ratios relative to control values after normalization to the internal control TBP-TATA-binding protein) was applied. $\mathrm{C}_{\mathrm{T}}$ values were derived using Bio-Rad CFX Manager 3.1.

\section{Primers}

TBP Forward: TGCACAGGAGCCAAGAGTGAA; Reverse: CACATCACAGCTCCCCACCA; CD133 Forward: CGTGGATGCAGAACTTGACAACGT; Reverse: ATACCTGCTACGACAGTCGTGGT; SOX2 Forward: GCCGAGTGGAAACTTTTGTCGGA; Reverse: CGTGTACTTATCCTTCTTCATGAGCGTC; OCT4 Forward: GGAGAAGGAGAAGCTGGAGCA; Reverse: GG CAGATGGTCGTTTGGCTGAATA; NANOG Forward: GTCTGGACACTGGCTGAATCCT; Reverse: CTCGCT GATTAGGCTCCAACCAT; MGMT Forward: CCTGG CTGAATGCCTATTTCCACCA; Reverse: GGATGAGG ATGGGGACAGGATTGC.

\section{Western blot analysis}

Total cell lysates were analyzed as described earlier [23]. The following antibodies were used: mouse anti-MGMT (Novus Biologicals; \#NB100-168), rabbit anti-PTCH2 (Cell Signaling; \#2464), rabbit anti-ASK1 (Cell Signaling; \#8662), rabbit anti-MDM2 (Thermo Fisher Scientific Pierce; \#PA5-11353), rabbit anti-p53 (Millipore; \#04-1083), rabbit anti-phospho-p53 (Ser6) (Millipore; \#04-540), rabbit anti-PARP (Cell Signaling; \#9542), rabbit anti-ERK1/2 (Millipore; \#06-182), rabbit anti-phospho-ERK1/2 (Thermo Scientific Pierce; \#MA5-1574), rabbit anti-AKT1 (Millipore; \#07-416), mouse anti-phospho-AKT1 (Santa Cruz; sc-52940), mouse anti- $\beta$-actin (Sigma-Aldrich; A1978), the Epithelial-Mesenchymal Transition antibody sampler kit (Cell Signaling; \#9782), anti- rabbit (Cell Signaling, \#7074) and anti-mouse (Cell Signaling, \#44209).

\section{Statistical analyses}

A two-sided t test was used to calculate the significance values (Statistica 10 Software, USA). Data showing $\mathrm{p}$ values of ${ }^{*} \mathrm{P}<0.05$, ${ }^{* * *} \mathrm{P}<0.01$, and ${ }^{* * *} \mathrm{P}<0.001$ were considered significant. All experimental data are reported as mean and the error bars represent the experimental standard error ( \pm standard deviation, SD). 


\section{Additional files}

Additional file 1: Table S1. A list of CCAs/NCCAs and their copy number variation in U251, U251TMZ1 and U251TMZ1 cells.

Additional file 2: Table S2. Table S2. Detailed description of copy number alterations (CNAs) in U251, U251TMZ1 and U251TMZ1 cells.

Additional file 3: Table S3. Table S3. A list of CCAs/NCCAs and their copy number variation in T98G and T98GTMZ cells.

Additional file 4: Table S4. Table S4. Detailed description of copy number alterations (CNAs) in T98G and T98GTMZ cells.

Additional file 5: Table S5. Table S5. A list of CCAs/NCCAs and their copy number variation in C6, C6TMZ, C6R1, and C6R2TMZ cells.

Additional file 6: Table S6. Table S6. Detailed description of copy number alterations (CNAs) in $\mathrm{C} 6$ and $\mathrm{C} 6 \mathrm{TMZ}$ cells.

Additional file 7: Table S7. Table S7. A list of annotated genes in gained 4p16.1-q26 region retrieved using a the DAVID bioinformatics resource or $b$ the NCBI Map Viewer. These lists of annotated genes were crosschecked with a manually curated list of published proteins/miRNAs that were shown to contribute to TMZ resistance (see Suppl. Table S8), and hits were marked with colour.

Additional file 8: Table S8. Table S8. A list of genes/proteins, which were experimentally shown to increase/reduce the sensitivity of tumour cells to temozolomide (TMZ) treatment.

Additional file 9: Figure S1. qRT-PCR analysis of selected genes in TMZ-treated cells. a The relative gene expression ratios (fold-change) of stem cell markers CD133, OCT4, SOX2, and NANOG. b The relative gene expression ratio (fold-change) of MGMT. Gene expression fold-change values were derived by $2^{-\triangle \Delta C T}$ method (expressed as ratios relative to control values after normalization to the internal control TBP). TBP - TATA-binding protein; CD133 - prominin 1; OCT4 - POU class 5 homeobox 1; SOX2 - SRY (sex determining region Y)-box 2; NANOG - Nanog homeobox; MGMT - 0-6-methylguanine-DNA methyltransferase.

\section{Abbreviations}

aCGH: array comparative genome hybridization; CIN: chromosome instability; CCAs: clonal chromosome aberrations; CNAs: copy number alterations; GSC: glioblastoma cancer stem cells; NCCAs: non-clonal chromosome aberrations; TEM: temsirolimus; TMZ: temozolomide.

\section{Authors' contributions}

Conception and design: AAS, VPB; Collection and assembly of data: AAS, SVA, KVK, DOM, VPB, NLH, OAK; Data analysis and interpretation: AAS, SVA, DOM; Contribution of reagents, materials, and analysis tools: KVK, YSV, VPC, SSA, VVD. AAS wrote the paper. All authors read and approved the final manuscript.

\section{Author details}

${ }^{1}$ Department of Biosynthesis of Nucleic Acids, Institute of Molecular Biology and Genetics, National Academy of Science of Ukraine, Zabolotnogo str. 150, Kiev 03680, Ukraine. ${ }^{2}$ Department of Medicinal Nanobiotechnology, Pirogov Russian State Medical University, Ostrovitianov str. 1, Moscow 117997, Russia. ${ }^{3}$ Federal Research and Clinical Centre, FMBA of Russia, Orekhoviy Bulvar str. 28, Moscow 115682, Russia. ${ }^{4}$ Department of Diagnostic of Hereditary Pathology, Institute of Hereditary Pathology, National Academy of Medical Sciences of Ukraine, Lysenko str. 31A, Lviv 79008, Ukraine. ${ }^{5}$ Department of Experimental Cell System, R.E.Kavetsky Institute of Experimental Pathology, Oncology and Radiobiology, National Academy of Science of Ukraine, Vasylkivska str. 45, Kiev 03022, Ukraine. ${ }^{6}$ Department of Human Genetics, Institute of Molecular Biology and Genetics, National Academy of Science of Ukraine, Zabolotnogo str. 150, Kiev 03680, Ukraine. ${ }^{7}$ CNRS UMR8126, Institut de Cancérologie Gustave Roussy, Université Paris-Sud 11, Camille-Desmoulins str. 39, Villejuif 94805, France.

\section{Acknowledgements}

We thank Ms. Shirmoné Botha for critical reading of the manuscript. This work was supported by National Academy of Sciences of Ukraine (NASU) as a framework of the program "Fundamental grounds of molecular and cell biotechnologies" №38/14 (2010-2014), joint Ukrainian-Austrian R\&D project M/192 "Investigation of the mechanisms of glioma chemoresistance and development of the approaches to glioma complex therapy", the Grant F1 "Human pathologies: from molecular to cellular events", and the Grant of Russian Scientific Foundation 14-14-00882.

\section{Competing interests}

The authors declare that they have no competing interests.

Received: 18 November 2015 Accepted: 26 April 2016

Published online: 05 May 2016

\section{References}

1. Yang L-J, Zhou C-F, Lin Z-X. Temozolomide and radiotherapy for newly diagnosed glioblastoma multiforme: a systematic review. Cancer Invest. 2014:32:31-6

2. Tatar Z, Thivat E, Planchat E, Gimbergues P, Gadea E, Abrial C, Durando X. Temozolomide and unusual indications: review of literature. Cancer Treat Rev. 2013;39:125-35.

3. McDermott M, Eustace AJ, Busschots S, Breen L, Crown J, Clynes M, O'Donovan N, Stordal B. In vitro development of chemotherapy and targeted therapy drug-resistant cancer cell lines: a practical guide with case studies. Front Oncol. 2014;4:40.

4. Leshchenko V, Kuo P-Y, Jiang Z, Thirukonda VK, Parekh S. Integrative genomic analysis of temozolomide resistance in diffuse large B-cell lymphoma. Clin Cancer Res. 2014;20:382-92.

5. Tentori L, Ricci-Vitiani L, Muzi A, Ciccarone F, Pelacchi F, Calabrese R, Runci D, Pallini R, Caiafa P, Graziani G. Pharmacological inhibition of poly(ADPribose) polymerase-1 modulates resistance of human glioblastoma stem cells to temozolomide. BMC Cancer. 2014;14:151.

6. Meyer M, Reimand J, Lan X, Head R, Zhu X, Kushida M, Bayani J, Pressey JC, Lionel AC, Clarke ID, Cusimano M, Squire JA, Scherer SW, Bernstein M, Woodin MA, Bader GD, Dirks PB. Single cell-derived clonal analysis of human glioblastoma links functional and genomic heterogeneity. Proc Natl Acad Sci USA. 2015;112:851-6.

7. Happold C, Roth P, WickW, Schmidt N, Florea A-M, Silginer M, Reifenberger $\mathrm{G}$, Weller M. Distinct molecular mechanisms of acquired resistance to temozolomide in glioblastoma cells. J Neurochem. 2012;122:444-55.

8. Lamoral-Theys D, Le Mercier M, Le Calvé B, Rynkowski MA, Bruyère C, Decaestecker C, Haibe-Kains B, Bontempi G, Dubois J, Lefranc F, Kiss R. Long-term temozolomide treatment induces marked amino metabolism modifications and an increase in TMZ sensitivity in Hs683 oligodendroglioma cells. Neoplasia. 2010;12:69-79.

9. Svilar D, Dyavaiah M, Brown AR, Tang J, Li J, McDonald PR, Shun TY, Braganza A, Wang X, Maniar S, St Croix CM, Lazo JS, Pollack IF, Begley TJ, Sobol RW. Alkylation sensitivity screens reveal a conserved cross-species functionome. Mol Cancer Res. 2012;10:1580-96.

10. Ye F, Zhang Y, Liu Y, Yamada K, Tso JL, Menjivar JC, Tian JY, Yong WH, Schaue D, Mischel PS, Cloughesy TF, Nelson SF, Liau LM, McBride W, Tso C-L. Protective properties of radio-chemoresistant glioblastoma stem cell clones are associated with metabolic adaptation to reduced glucose dependence. PLOS ONE. 2013;8:e80397.

11. Auger N, Thillet J, Wanherdrick K, Idbaih A, Legrier M-E, Dutrillaux B, Sanson M, Poupon M-F. Genetic alterations associated with acquired temozolomide resistance in SNB-19, a human glioma cell line. Mol Cancer Ther. 2006;5:2182-92.

12. Hiddingh L, Raktoe RS, Jeuken J, Hulleman E, Noske DP, Kaspers GJL, Vandertop WP, Wesseling P, Wurdinger T. Identification of temozolomide resistance factors in glioblastoma via integrative miRNA/mRNA regulatory network analysis. Sci Rep. 2014;4:5260 
13. Kumar DM, Patil V, Ramachandran B, Nila MV, Dharmalingam K, Somasundaram K. Temozolomide-modulated glioma proteome: role of interleukin-1 receptor-associated kinase-4 (IRAK4) in chemosensitivity. Proteomics. 2013;13:2113-24.

14. Sun S, Wong TS, Zhang XQ, Pu JKS, Lee NP, Day PJR, Ng GKB, Lui WM, Leung GKK. Protein alterations associated with temozolomide resistance in subclones of human glioblastoma cell lines. J Neurooncol. 2012;107:89-100.

15. Anderson JC, Duarte CW, Welaya K, Rohrbach TD, Bredel M, Yang ES, Choradia NV, Thottassery JV, Yancey Gillespie G, Bonner JA, Willey CD. Kinomic exploration of temozolomide and radiation resistance in Glioblastoma multiforme xenolines. Radiother Oncol. 2014;111:468-74.

16. Bruyère C, Mijatovic T, Lonez C, Spiegl-Kreinecker S, Berger W, Kast RE, Ruysschaert J-M, Kiss R, Lefranc F. Temozolomide-induced modification of the CXC chemokine network in experimental gliomas. Int J Oncol. 2011;38:1453-64.

17. Griguer $C E$, Oliva CR. Bioenergetics pathways and therapeutic resistance in gliomas: emerging role of mitochondria. Curr Pharm Des. 2011;17:2421-7.

18. Kohsaka S, Wang L, Yachi K, Mahabir R, Narita T, Itoh T, Tanino M, Kimura T, Nishihara H, Tanaka S. STAT3 inhibition overcomes temozolomide resistance in glioblastoma by downregulating MGMT expression. Mol Cancer Ther. 2012;11:1289-99.

19. Le Calvé B, Rynkowski M, Le Mercier M, Bruyère C, Lonez C, Gras T, Haibe-Kains B, Bontempi G, Decaestecker C, Ruysschaert J-M, Kiss R, Lefranc F. Long-term in vitro treatment of human glioblastoma cells with temozolomide increases resistance in vivo through up-regulation of GLUT transporter and aldo-keto reductase enzyme AKR1C expression. Neoplasia. 2010;12:727-39.

20. Ma J, Murphy M, O'Dwyer PJ, Berman E, Reed K, Gallo JM. Biochemical changes associated with a multidrug-resistant phenotype of a human glioma cell line with temozolomide-acquired resistance. Biochem Pharmacol. 2002;63:1219-28.

21. Oliva CR, Nozell SE, Diers A, McClugage SG, Sarkaria JN, Markert JM, Darley-Usmar VM, Bailey SM, Gillespie GY, Landar A, Griguer CE. Acquisition of temozolomide chemoresistance in gliomas leads to remodeling of mitochondrial electron transport chain. J Biol Chem. 2010;285:39759-67.

22. Oliva CR, Moellering DR, Gillespie GY, Griguer CE. Acquisition of chemoresistance in gliomas is associated with increased mitochondrial coupling and decreased ROS production. PLoS ONE. 2011;6:e24665.

23. Stepanenko A, Andreieva S, Korets K, Mykytenko D, Huleyuk N, Vassetzky Y, Kavsan V. Step-wise and punctuated genome evolution drive phenotype changes of tumor cells. Mutat Res Mol Mech Mutagen. 2015;771:56-69.

24. Lee AJX, Endesfelder D, Rowan AJ, Walther A, Birkbak NJ, Futreal PA, Downward J, Szallasi Z, Tomlinson IPM, Howell M, Kschischo M, Swanton C. Chromosomal instability confers intrinsic multidrug resistance. Cancer Res. 2011:71:1858-70.

25. Stepanenko AA, Vassetzky YS, Kavsan VM. Antagonistic functional duality of cancer genes. Gene. 2013;529:199-207.

26. Stepanenko AA, Kavsan VM. Evolutionary karyotypic theory of cancer versus conventional cancer gene mutation theory. Biopolym Cell. 2012;28:267-80.

27. Stepanenko AA, Kavsan VM. Karyotypically distinct U251, U373, and SNB19 glioma cell lines are of the same origin but have different drug treatment sensitivities. Gene. 2014;540:263-5.

28. Heng HHQ, Stevens JB, Bremer SW, Ye KJ, Liu G, Ye CJ. The evolutionary mechanism of cancer. J Cell Biochem. 2010;109:1072-84.

29. Heng HHQ, Bremer SW, Stevens JB, Ye KJ, Liu G, Ye CJ. Genetic and epigenetic heterogeneity in cancer: a genome-centric perspective. J Cell Physiol. 2009;220:538-47.

30. Duesberg P, Li R, Sachs R, Fabarius A, Upender MB, Hehlmann R. Cancer drug resistance: the central role of the karyotype. Drug Resist Updat. 2007;10:51-8

31. Li R, Hehlman R, Sachs R, Duesberg P. Chromosomal alterations cause the high rates and wide ranges of drug resistance in cancer cells. Cancer Genet Cytogenet. 2005;163:44-56.

32. Stepanenko AA, Kavsan VM. Immortalization and malignant transformation of Eukaryotic cells. Cytol Genet. 2012;46:96-129.
33. Duesberg P, Mandrioli D, McCormack A, Nicholson JM. Is carcinogenesis a form of speciation? Cell Cycle. 2011;10:2100-14.

34. Horne SD, Stevens JB, Abdallah BY, Liu G, Bremer SW, Ye CJ, Heng HHQ. Why imatinib remains an exception of cancer research. J Cell Physiol. 2013;228:665-70.

35. Geigl JB, Obenauf AC, Schwarzbraun T, Speicher MR. Defining "chromosomal instability". Trends Genet. 2008;24:64-9.

36. Van Thuijl HF, Mazor T, Johnson BE, Fouse SD, Aihara K, Hong C, Malmström A, Hallbeck M, Heimans JJ, Kloezeman JJ, Stenmark-Askmalm M, Lamfers MLM, Saito N, Aburatani H, Mukasa A, Berger MS, Söderkvist P, Taylor BS, Molinaro AM, Wesseling P, Reijneveld JC, Chang SM, YIstra B, Costello JF. Evolution of DNA repair defects during malignant progression of low-grade gliomas after temozolomide treatment. Acta Neuropathol. 2015;129:597-607.

37. Kim H, Zheng S, Amini SS, Virk SM, Mikkelsen T, Brat DJ, Grimsby J, Sougnez C, Muller F, Hu J, Sloan AE, Cohen ML, Van Meir EG, Scarpace L, Laird PW, Weinstein JN, Lander ES, Gabriel S, Getz G, Meyerson M, Chin L, Barnholtz-Sloan JS, Verhaak RGW. Whole-genome and multisector exome sequencing of primary and post-treatment glioblastoma reveals patterns of tumor evolution. Genome Res. 2015;25:316-27.

38. Johnson BE, Mazor T, Hong C, Barnes M, Aihara K, McLean CY, Fouse SD, Yamamoto S, Ueda H, Tatsuno K, Asthana S, Jalbert LE, Nelson SJ, Bollen AW, Gustafson WC, Charron E, Weiss WA, Smirnov IV, Song JS, Olshen AB, Cha S, Zhao Y, Moore RA, Mungall AJ, Jones SJM, Hirst M, Marra MA, Saito $\mathrm{N}$, Aburatani $\mathrm{H}$, Mukasa A, et al. Mutational analysis reveals the origin and therapy-driven evolution of recurrent glioma. Science. 2014;343:189-93.

39. Huang DW, Sherman BT, Lempicki RA. Systematic and integrative analysis of large gene lists using DAVID bioinformatics resources. Nat Protoc. 2009:4:44-57.

40. Zhou Q, Guo P, Kruh GD, Vicini P, Wang X, Gallo JM. Predicting human tumor drug concentrations from a preclinical pharmacokinetic model of temozolomide brain disposition. Clin Cancer Res. 2007;13:4271-9.

41. Yusubalieva GM, Baklaushev VP, Gurina OI, Zorkina YA, Gubskii IL, Kobyakov GL, Golanov AV, Goryainov SA, Gorlachev GE, Konovalov AN, Potapov AA, Chekhonin VP. Treatment of poorly differentiated glioma using a combination of monoclonal antibodies to extracellular connexin-43 fragment, temozolomide, and radiotherapy. Bull Exp Biol Med. 2014;157:510-5.

42. Oliveira R, Christov C, Guillamo JS, de Boüard S, Palfi S, Venance L, Tardy M, Peschanski M. Contribution of gap junctional communication between tumor cells and astroglia to the invasion of the brain parenchyma by human glioblastomas. BMC Cell Biol. 2005;6:7.

43. Chen W, Wang D, Du X, He Y, Chen S, Shao Q, Ma C, Huang B, Chen A, Zhao P, Qu X, Li X. Glioma cells escaped from cytotoxicity of temozolomide and vincristine by communicating with human astrocytes. Med Oncol. 2015;32:487.

44. Galvao J, Davis B, Tilley M, Normando E, Duchen MR, Cordeiro MF. Unexpected low-dose toxicity of the universal solvent DMSO. FASEB J. 2014;28:1317-30.

45. Stepanenko AA, Dmitrenko VV. Pitfalls of the MTT assay: direct and off-target effects of inhibitors can result in over/underestimation of cell viability. Gene. 2015;574:193-203.

46. Spiegl-Kreinecker S, Pirker C, Marosi C, Buchroithner J, Pichler J, Silye R, Fischer J, Micksche M, Berger W. Dynamics of chemosensitivity and chromosomal instability in recurrent glioblastoma. Br J Cancer. 2007:96:960-9.

47. Thon N, Kreth S, Kreth F-W. Personalized treatment strategies in glioblastoma: MGMT promoter methylation status. Onco Targets Ther. 2013;6:1363-72.

48. Wick W, Weller M, van den Bent M, Sanson M, Weiler M, von Deimling A, Plass C, Hegi M, Platten M, Reifenberger G. MGMT testing-the challenges for biomarker-based glioma treatment. Nat Rev Neurol. 2014;10:372-85.

49. Brennan CW, Verhaak RGW, McKenna A, Campos B, Noushmehr H, Salama SR, Zheng S, Chakravarty D, Sanborn JZ, Berman SH, Beroukhim R, Bernard B, Wu C-J, Genovese G, Shmulevich I, Barnholtz-Sloan J, Zou L, Vegesna R, Shukla SA, Ciriello G, Yung WK, Zhang W, Sougnez C, Mikkelsen T, Aldape K, Bigner DD, Van Meir EG, Prados M, Sloan A, Black KL, et al. The somatic genomic landscape of glioblastoma. Cell. 2013;155:462-77. 
50. Agnihotri S, Burrell K, Buczkowicz P, Remke M, Golbourn B, Chornenkyy Y, Gajadhar A, Fernandez NA, Clarke ID, Barszczyk MS, Pajovic S, Ternamian C, Head R, Sabha N, Sobol RW, Taylor MD, Rutka JT, Jones C, Dirks PB, Zadeh G, Hawkins C. ATM regulates 3-methylpurine-DNA glycosylase and promotes therapeutic resistance to alkylating agents. Cancer Discov. 2014:4:1198-213.

51. Yoshimoto K, Mizoguchi M, Hata N, Murata H, Hatae R, Amano T, Nakamizo A, Sasaki T. Complex DNA repair pathways as possible therapeutic targets to overcome temozolomide resistance in glioblastoma. Front Oncol. 2012;2:186.

52. Stieber D, Golebiewska A, Evers L, Lenkiewicz E, Brons NHC, Nicot N, Oudin A, Bougnaud S, Hertel F, Bjerkvig R, Vallar L, Barrett MT, Niclou SP. Glioblastomas are composed of genetically divergent clones with distinct tumourigenic potential and variable stem cell-associated phenotypes. Acta Neuropathol. 2014;127:203-19.

53. Auffinger B, Tobias AL, Han Y, Lee G, Guo D, Dey M, Lesniak MS, Ahmed AU. Conversion of differentiated cancer cells into cancer stem-like cells in a glioblastoma model after primary chemotherapy. Cell Death Differ. 2014;21:1119-31.

54. Fouse SD, Nakamura JL, James CD, Chang S, Costello JF. Response of primary glioblastoma cells to therapy is patient specific and independent of cancer stem cell phenotype. Neuro Oncol. 2014:16:361-71.

55. Pachow D, WickW, Gutmann DH, Mawrin C. The mTOR signaling pathway as a treatment target for intracranial neoplasms. Neuro Oncol. 2015;17:189-99.
56. Kuhn JG, Chang SM, Wen PY, Cloughesy TF, Greenberg H, Schiff D, Conrad C, Fink KL, Robins HI, Mehta M, DeAngelis L, Raizer J, Hess K, Lamborn KR, Dancey J, Prados MD. Pharmacokinetic and tumor distribution characteristics of temsirolimus in patients with recurrent malignant glioma. Clin Cancer Res. 2007;13:7401-6.

57. Stepanenko AA, Andreieva SV, Korets KV, Mykytenko DO, Baklaushev VP, Chekhonin VP, Dmitrenko VV. mTOR inhibitor temsirolimus and MEK1/2 inhibitor U0126 promote chromosomal instability and cell type-dependent phenotype changes of glioblastoma cells. Gene. 2016;579:58-68.

58. Yin A, Cheng J, Zhang X, Liu B. The treatment of glioblastomas: a systematic update on clinical Phase III trials. Crit Rev Oncol Hematol. 2013;87:265-82.

59. Baklaushev VP, Nukolova NN, Khalansky AS, Gurina OI, Yusubalieva GM, Grinenko NP, Gubskiy IL, Melnikov PA, Kardashova KS, Kabanov AV, Chekhonin VP. Treatment of glioma by cisplatin-loaded nanogels conjugated with monoclonal antibodies against Cx43 and BSAT1. Drug Deliv. 2014;22:276-85.

60. Geissmann Q. OpenCFU, a new free and open-source software to count cell colonies and other circular objects. PLoS ONE. 2013;8:e54072.

61. Gebäck T, Schulz MMP, Koumoutsakos P, Detmar M. TScratch: a novel and simple software tool for automated analysis of monolayer wound healing assays. Biotechniques. 2009:46:265-74.

62. Yip S, Miao J, Cahill DP, lafrate AJ, Aldape K, Nutt CL, Louis DN. MSH6 mutations arise in glioblastomas during temozolomide therapy and mediate temozolomide resistance. Clin Cancer Res. 2009;15:4622-9.

\section{Submit your next manuscript to BioMed Central and we will help you at every step:}

- We accept pre-submission inquiries

- Our selector tool helps you to find the most relevant journal

- We provide round the clock customer support

- Convenient online submission

- Thorough peer review

- Inclusion in PubMed and all major indexing services

- Maximum visibility for your research

Submit your manuscript at www.biomedcentral.com/submit
() Biomed Central 